\title{
-New Books
}

\section{E\&MJ INTERNATIONAL DIRECTORY OF MINING}

This directory of mining has been updated and contains 825 pages of key names and profiles of mineral-producing, processing and marketing companies. It lists more than $85 \%$ of the world's mine and minerals processing plants. The following information can be found in this handbook: companies producing the world's minerals, mine and plant units, mineral sales organisations, ore buyers, mine company data, consultants, financial institutions and mine bureaus.

Maclean Hunter Publishing company, Mining Information Services (USA), 1994, 825 pp., US $\$ 120.00$.

\section{DICTIONARY OF MINING TERMS}

This dictionary covers metal mining, coal, quarrying, geology, metallurgy and mineral/mineralogy. It contains 55000 basic terms, 150000 definitions, arranged alphabetically.

Maclean Hunter Publishing Co. (USA), 1993, 1270 pp.,US\$76.00

\section{S. HORIUCHI: FUNDAMENTALS OF HIGH-RESOLUTION TRANSMISSION ELECTRON MICROSCOPY}

The main purpose of this book is to show the fundamental concept on the principles of high-resolution transmission electron microscopy (HRTEM) and how to utilise it. In chapters 2 and 3 two important mechanical constituents of TEM, electron lens and electron gun, are summarised. In chapters 4 to 7 the optical and electron-optical theories on the formation of a HRTEM image are described. In chapter 8 some practical procedures for observing and analysing images are shown. In chapter 9 some experimental data for analysing high- $\mathbf{T}_{c}$ superconducting materials are presented to demonstrate how the HRTEM is applied to real problems and how the results obtained serve in materials science.

North-Holland, Elsevier Science, Amsterdam, 1994, 360 pp., US\$214.25

\section{A.K. BISWAS AND W.G. DAVENPORT: EXTRACTIVE METALLURGY OF COPPER}

This is the third and revised edition and contains comprehensive industrial data. The many significant changes which occurred during the 1980s and 1990s are summarised. Modern high-intensity smelting processes are presented and recent developments in electrorefining, leaching, solvent extraction and electrowinning are examined.

Pergamon (Elsevier), 1994, 490 pp., US $\$ 88.00$ 


\section{MINING AND METALLURGY IN SOUTH AFRICA: A PICTORIAL HISTORY}

Compiled by A.J. Cowey

This book was produced to celebrate the centenary of the South African Institute of Mining and Metallurgy and 60 years of Mintek. The publication is divided into chapters according to materials abundant in South Africa. In each chapter the history of each commodity and developments in mining and extraction technologies are outlined. The text is accompanied by a wealth of photographs which capture the development of South African mining.

Published by Mintek, Randburg, South Africa, 1994, 120 pp, US $\$ 55.00$

\section{P. CAMPBELL: PERMANENT MAGNET MATERIALS AND THEIR APPLICATION}

This book is a comprehensive design text for permanent magnets and their application. The book covers all aspects of modern permanent magnets, with special emphasis on rare earth magnets. The core of the book is devoted to a detailed treatment of the methods that are used to design permanent magnets, including assessments of the changes they experience under practical operating conditions. modern analytical methods are described, including the finite element method, with reference to the accurate simulation of permanent magnet materials. Cambridge University Press, Cambridge, 1994, 207 pp, US\$49.95

\section{INDUSTRIAL MINERALS AND ROCKS}

D.D. Carr (Senior Editor)

The 6th edition of this handbook is an updated version of the 5th edition published 11 years ago. An introduction includes tables of the US industrial mineral statistics and prices, a discussion of the world distribution of mineral deposits, international trade and laws relating to industrial minerals production. Following the introduction are 88 chapters that cover all of the major and many of the minor industrial minerals.

Published by the Society for Mining, Metallurgy and Exploration, Inc., Littleton USA, 1994, $1213 \mathrm{pp}$, US $\$ 138.50$ 